\title{
肺高血圧症における 4D Flow MRI
}

\author{
大田英揮
}

東北大学大学院医学系研究科先進 MRI 共同研究講座

\section{はじめに}

肺高血圧症が疑われる患者に対して汎用さ れ，使用適性度の高い検査は，経胸壁超音波検 查, 胸部単純 $\mathrm{X}$ 線である ${ }^{11}$. MRI はアクセス ビリティー・煩雑さなどから，より精査が必要 な場合に用いられているが，被曝がなく優れた 非侵襲的画像モダリティーであり，包括的な画 像評価が可能である。近年発展してきた $4 \mathrm{D}$ Flow MRI では， 3 次元的な肺動脈血流評価が 可能であり，肺高血圧症に抢ける MRIの診断 的価值をさらに高める可能性を有している.

本稿では, 肺高血圧症の基本的事項の解説 と, 4D Flow MRI の肺高血圧症における臨床 応用について最近の知見の紹介をする.

\section{肺高血圧症の臨床的定義と分類}

肺高血圧の領域では，1973 年から始をり， 近年は 5 年ごとに開催されるWorld Symposium on Pulmonary Hypertension (WSPH) に 抢いて, 定義や学術・臨床的な進渉, 将来の ニーズなどが議論される. 従来, 肺高血圧症の 定義は右心カテーテル検查で平均肺動脈圧 $\geqq$ $25 \mathrm{mmHg}$ 以上とされてきた。 また, 平均肺動 脈 $\leqq 20 \mathrm{mmHg}$ を正常とし，21〜24 mmHg を 境界域の肺高血圧症として扱ってきた。 2018 年に Nice で開催された 6 th WSPH において, 境界域症例のうち肺血管抵抗 $\geq 3 \mathrm{WU}$ である場 合を前毛細血管性肺高血圧症に含むことが提案
された2).

肺高血圧症の臨床分類は その原因によって 5 群に大きく分けられる（1 群：肺動脈性肺高 血圧症, 2 群 : 左心疾患に伴う肺高血圧症, 3 群：肺疾患や低酸素血症に伴う肺高血圧症，4 群 : 慢性血栓塞栓性肺高血圧症, 5 群 : 原因不 明あるいは多因子による肺高血圧症 $)^{3)}$ 。実際 の臨床では, 複数の群にまたがる成因が考えら れるような症例（3 群に 1 群の要素を含む例な ど）も考えられ，病態は複雑なこともある.肺 高血圧症の臨床症状としては労作時呼吸困難 や, 易疲労感, 胸痛, 失神などによる活動制限 であり, 疾患特異性が高いわけではないが，症 状の重症度は予後とも関連する.

肺高血圧症が疑われる場合にはスクリーニン グ検査として，経胸壁エコーが一般的に行われ る. その他, $\mathrm{CT}$ や $\mathrm{V} / \mathrm{Q}$ スキヤン, MRI を含 む複数の画像診断を参考にし，最終的には右心 カテーテル検查によって, 肺高血圧症の確定診 断となる. 臨床分類の最終的な診断は各種画像 データおよび臨床的データによる包括的な評価 をもって行われる。

\section{肺高血圧症における cardiovascular magnetic resonance (CMR)}

CMR の肺高血圧症の診療における役割を Table に示す1). CMR は右心機能・右心形態 の画像的評価法としてのゴールドスタンダード であり，非侵襲性で再現性が高く，死角がない

この総説は, 第 46 回日本磁気共鳴医学会大会シンポジウム「Can 4D-Flow Make a Clinical Breakthrough?」で の講演を中心にまとめたものである.

キーワード pulmonary hypertension, magnetic resonance imaging, 4D Flow MRI, wall shear stress 
Table. Role of cardiac magnetic resonance for pulmonary hypertension

\section{- Cine MRI}

Morphology and function : right ventricular (RV) hypertrophy, RV dilatation, tricuspid valve deformation, flattening of the intraventricular septum (IVS), paradoxical motion of the IVS, pericardial effusion, pleural effusion, visual assessment of the blood flow, regional wall motion by strain analysis.

- Late gadolinium enhancement/ $\mathrm{T}_{1}$ map

Myocardial tissue characteristics, positive enhancement at the right ventricular insertion point, prolonged $\mathrm{T}_{1}$ in the myocardium.

-2D phase-contrast MRI

Blood flow velocity, regurgitant fraction, Qp/Qs, distensibility

-4D Flow MRI

Parameters obtained by 2D phase-contrast MRI, three-dimensional blood flow pattern, vortical flow, wall shear stress.

- MR angiography

Evaluation of pulmonary vasculature

という利点がある、肺高血圧症では, 心室中隔 の平坦化·奇異性運動, 右室拡大, 右室壁肥厚 および，右室の丸みを帯びた形態変化などを，

シネ MRI で詳細に観察することが可能であ る. 右室機能評価法として, volumetry による 拡張末期 ·収縮末期容積係数や駆出率, 心拍出 係数, 心室重量係数などは, 肺高血圧症の重症 度や予後を反映し得るパラメーターとな $ろ^{4), 5)}$. 遅延造影 MRI では, 右室接合部の遅 延造影が，肺高血圧症の症例で高頻度に認めら れる。これは右室接合部の機械的ストレスの増 加による線維化や炎症, および心筋繊維の錯綜 などによるものと考えられている6 ${ }^{6}$. また, 右 室接合部から心室中隔にも遅延造影域が進展し 得る. 遅延造影の程度は, 右室機能不全とも相 関すると報告されている.

Phase-contrast MRI では, 平均肺動脈血流 速度と, 平均肺動脈圧が相関することが知られ て抢り, 平均肺動脈血流速度のカットオフ值を $11.7 \mathrm{~cm} / \mathrm{s}$ とした場合, 平均肺動脈 $>25$ $\mathrm{mmHg}$ となる感度・特異度はそれぞれ $93 \%$, $82 \%$ と報告されている7)。 また, phase-contrast MRI で計測された肺動脈の distensibility （心周期における肺動脈断面積の変化）と肺血 管抵抗の相関や運動耐容能の関連性があるとも 報告されている8).

MR angiography（MRA）では CT angiog- raphy と同様に，肺血管の解剖を評価する．肺 高血圧症では一般的に肺動脈の中枢側が著明 に拡張し，末梢側が枯れ枝状になり狭小化す る.さらに 4 群の慢性血栓塞栓性肺高血圧症 では，特徵的な血管造影所見があり，それらの 所見も（空間分解能の限界があるが） ある程度 描出することが可能である.

\section{D Flow MRI}

肺血管の 4D Flow MRI では，多くは肺動脈 幹〜左右主肺動脈レベルの中枢側血管に関する 報告が多い。体幹部の 4D Flow MRI では呼吸 同期の設定や，加算回数をあげることによる撮 像時間の限界が生じるため, 空間分解能との卜 レードオフが生じる. そのため, 通常は末梢側 肺動脈の評価を行うのは難しい。したがって, 多くの肺高血圧症の病変部位である末梢の肺血 管床の評価を 4D Flow MRI で表現すること は, 現時点ではほぼ不可能である. 一方で, 肺 動脈圧，肺血管抵抗の上昇により，中枢側肺動 脈にもリモデリングが生じ，拡張，硬化する. 中枢側であれば，4D Flow MRIにおける空間 分解能の限界も許容できる.

4D Flow MRI で肺動脈血流を観察すると, 正常例では直線的で, 乱れのない流線を描く (Fig. 1)。それに対して, 平均肺動脈が上昇す 


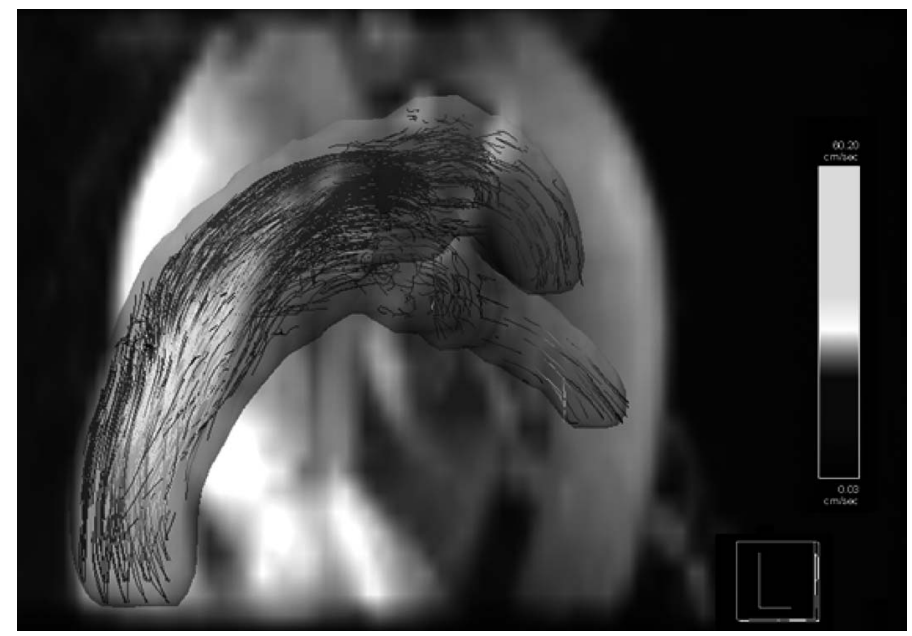

Fig. 1. 4D Flow MRI of a normal case

Streamline image. Linear blood flow is visualized in the pulmonary trunk at a systolic phase. Scan protocols: 3dimensional phase-contrast MR imaging with 3-directional velocity encoding in transverse slab orientation; ECG gating; TR/TE, $52.4 \mathrm{~ms} / 3.43 \mathrm{~ms}$; flip angle, 15 degrees; velocity encoding, $50-110 \mathrm{~cm} / \mathrm{s}$, determined by $2 \mathrm{D}$ phase contrast image at the main pulmonary trunk to avoid aliasing; the number of cardiac phases, 13-18, depending on heart rates, voxel size, $2.4 \mathrm{~mm} \times 1.8 \mathrm{~mm} \times 3.5 \mathrm{~mm}$; the number of slices, 30 .

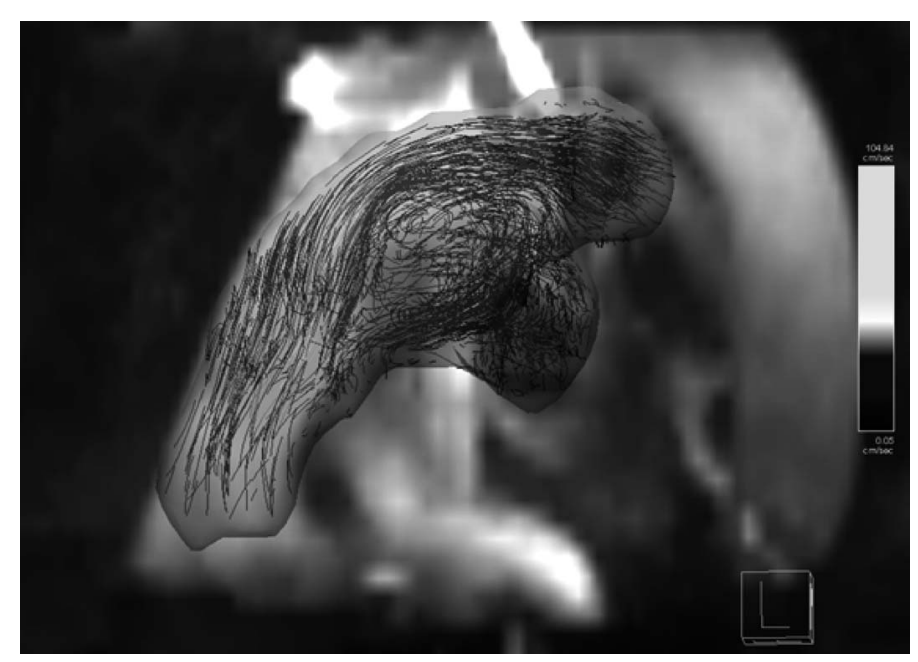

Fig. 2. 4D Flow MRI of a case with pulmonary hypertension (mean pulmonary arterial pressure of $40 \mathrm{mmHg}$ ) Streamline image. Vortical flow pattern is observed in the pulmonary trunk at a systolic phase.

るに従って，肺動脈幹内に渦流が形成され，そ れが明瞭化することが報告されている9 〜 11) (Fig. 2). また，一心拍内に拈いて渦流の出現 している時間が，平均肺動脈压と相関する（ $r^{2}$ $=0.95)$. 一心拍内で渦流の出現している時間 における肺高血圧症診断に対する area under the curve は 0.99 と非常に高く, その相対的出
現時間 14.3\%をカットオフ值とした場合，肺 高血圧症に対する感度・特異度はそれぞれ 97 $\%, 96 \%$ であった ${ }^{12)}$. 肺高血压症では肺動脈幹 が拡張することが知られており，CT P MRI を用いた研究では, 肺動脈径 $29 \mathrm{~mm}$ 以上や肺 動脈幹径/上行大動脈径比 $>1$ などが, 肺高血 圧症を示唆するカットオフ值として提案されて 
いる13) 15) . 肺動脈幹の拡張という肺高血圧に おける二次的な形態変化が, 渦流の形成に関与 していることが推測される。しかしながら，一 般健常人を対象にした研究に抢いて, 肺高血圧 症の既往歴を有していなくても3\%程度に渦流 の形成が認められたと報告されている16)。健 常人に打いても，肺動脈幹から左右に分岐する 形態が，渦流形成に影響している可能性があ る。

4D Flow MRI では血流形態のみならず，中 枢側肺動脈内の血流速度プロファイルを取得 し，壁剪断応力を解析することも可能である (Fig. 3)．血管壁のリモデリングには，血流に よる力学的刺激が関与すると考えられている. 壁剪断応力が血管平滑筋に影響を及ぼし, 組織 性状に変化が生じ，最終的に血管形状のリモデ リングに至る. Barker らは，健常な 19 例と肺 高血圧症の 19 例に対して4D Flow MRI を撮 像し, 肺動脈径, 収縮期最高血流速度 (Vmax), 最高血流量 ( $\mathrm{Qmax})$, 一回拍出量, 壁剪断応力を肺動脈幹, 左右主肺動脈で計測し た17)。いずれの部位に拈いても，肺高血圧症 の群で Vmax, Qmax, 一回拍出量, 壁剪断応 力は，健常群より低值であった。 Odagiri ら
も，肺高血圧症の症例に 4D Flow MRI を撮像 し, 肺動脈幹の渦流形成, 収縮期での肺動脈幹 内後ろ向き血流，壁剪断応力の低下が，肺高血 圧症で観察されたことを報告している11).

4 群の慢性血栓塞栓性肺高血圧症は, 器質化 した血栓による肺動脈狭窄・閉塞と二次的な血 管のリモデリングにより肺高血圧症に至る．急 性肺塞栓のエピソードを有するのは $0.1 〜 8.8 \%$ 程度で, 明確な既往歴を有しない症例も多 (18)。従来は，外科的血管内膜摘除術のみ が，薬物治療以外の介入法であったが，近年は 国内から積極的に肺動脈バルーン拡張術の有効 性が報告されて抢り，予後が改善してきてい る ${ }^{19)}$. 肺動脈バルーン拡張術前後で比較する と, 右室形態, 機能の改善が得られる. また, 肺血流速度の改善が得られ，4D Flow MRI で は肺動脈幹に見られる渦流の程度も改善す $ろ^{10), 20)}$.

\section{まとめ}

肺高血圧症の基本的な事項と，同疾患に抢け る cardiovascular MRI の役割について概説し た.4D Flow MRI は肺高血圧症に抢ける中枢

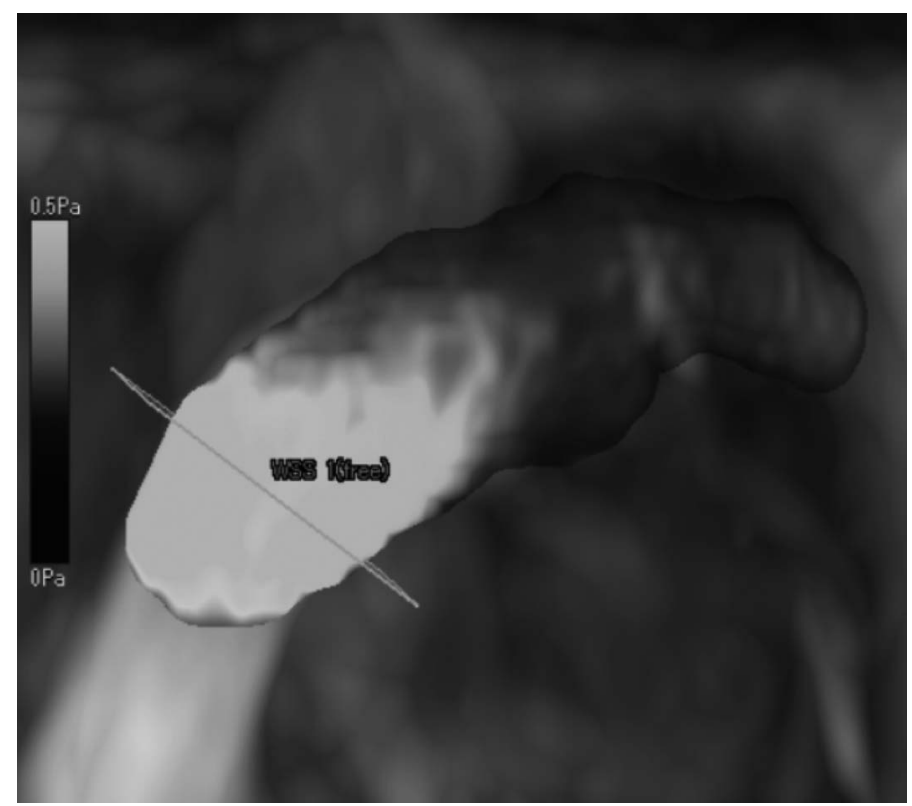

Fig. 3. 4D Flow MRI of a case with pulmonary hypertension (mean pulmonary arterial pressure of $30 \mathrm{mmHg}$ ): Distribution of wall shear stress at a systolic phase. 
側肺動脈の血流動態変化を反映した所見を得る ことができる。4D Flow MRIで得られる parameter 臨床的予後, 重症度に関する研究 は，今後さらに発展していく可能性があると考 えられる。

\section{文献}

1) Sirajuddin A, Donnelly EF, Crabtree TP, et al. : ACR Appropriateness Criteria ${ }^{\circledR}$ suspected pulmonary hypertension. J Am Coll Radiol 2017; 14 : S350-S361

2) Galiè N, McLaughlin VV, Rubin LJ, Simonneau $\mathrm{G}$ : An overview of the 6th World Symposium on Pulmonary Hypertension. Eur Respir J 2019; $53: 1802148$

3) Simonneau G, Montani D, Celermajer DS, et al. : Haemodynamic definitions and updated clinical classification of pulmonary hypertension. Eur Respir J 2018 : 1801913

4) Saba TS, Foster J, Cockburn M, Cowan M, Peacock AJ : Ventricular mass index using magnetic resonance imaging accurately estimates pulmonary artery pressure. Eur Respir J 2002 ; $20: 1519-1524$

5) Swift AJ, Rajaram S, Hurdman J, et al. : Noninvasive estimation of $\mathrm{PA}$ pressure, flow, and resistance with CMR imaging: derivation and prospective validation study from the ASPIRE registry. JACC Cardiovasc Imaging 2013;6: 1036-1047

6) Peña E, Dennie C, Veinot J, Muñiz SH : Pulmonary hypertension: how the radiologist can help. Radiographics $2012 ; 32: 9-32$

7) Sanz J, Kuschnir P, Rius T, et al. : Pulmonary arterial hypertension: noninvasive detection with phase-contrast MR imaging. Radiology 2007; $243: 70-79$

8) Kang KW, Chang HJ, Kim YJ, et al. : Cardiac magnetic resonance imaging-derived pulmonary artery distensibility index correlates with pulmonary artery stiffness and predicts functional capacity in patients with pulmonary arterial hypertension. Circ J $2011: 75: 2244-2251$

9) Reiter G, Reiter U, Kovacs G, et al. : Magnetic resonance-derived 3-dimensional blood flow patterns in the main pulmonary artery as a marker of pulmonary hypertension and a measure of elevated mean pulmonary arterial pressure. Circ
Cardiovasc Imaging $2008 ; 1: 23-30$

10) Ota $H$, Sugimura $K$, Miura $M$, Shimokawa $H$ : Four-dimensional flow magnetic resonance imaging visualizes drastic change in vortex flow in the main pulmonary artery after percutaneous transluminal pulmonary angioplasty in a patient with chronic thromboembolic pulmonary hypertension. Eur Heart J $2015 ; 36: 1630$

11) Odagiri $K$, Inui $N$, Hakamata $A$, et al. : Non-invasive evaluation of pulmonary arterial blood flow and wall shear stress in pulmonary arterial hypertension with 3D phase contrast magnetic resonance imaging. Springerplus $2016 ; 5: 1071$

12) Reiter G, Reiter U, Kovacs G, Olschewski H, Fuchsjäger $\mathrm{M}$ : Blood flow vortices along the main pulmonary artery measured with MR imaging for diagnosis of pulmonary hypertension. Radiology $2015 ; 275$ : 71-79

13) Tan RT, Kuzo R, Goodman LR, Siegel R, Haasler GB, Presberg KW : Utility of CT scan evaluation for predicting pulmonary hypertension in patients with parenchymal lung disease. Medical College of Wisconsin Lung Transplant Group. CHEST 1998 ; 113 : 1250-1256

14) Ng CS, Wells AU, Padley SP : A CT sign of chronic pulmonary arterial hypertension : the ratio of main pulmonary artery to aortic diameter. J Thorac Imaging $1999 ; 14: 270-278$

15) Boerrigter B, Mauritz GJ, Marcus JT, et al. : Progressive dilatation of the main pulmonary artery is a characteristic of pulmonary arterial hypertension and is not related to changes in pressure. CHEST $2010 ; 138: 1395-1401$

16) Wehrum $T$, Hagenlocher $P$, Lodemann $T$, et al. : Age dependence of pulmonary artery blood flow measured by $4 \mathrm{D}$ flow cardiovascular magnetic resonance : results of a population-based study. J Cardiovasc Magn Reson 2016 ; $18: 31$

17) Barker AJ, Roldan-Alzate A, Entezari P, et al. : Four-dimensional flow assessment of pulmonary artery flow and wall shear stress in adult pulmonary arterial hypertension : results from two institutions. Magn Reson Med 2015 ; 73 : 19041913

18) Fernandes $T$, Auger $W$, Fedullo $P$ : Epidemiology and risk factors for chronic thromboembolic pulmonary hypertension. Thromb Res 2018; $164: 145-149$

19) Aoki T, Sugimura K, Tatebe $S$, et al. : Comprehensive evaluation of the effectiveness and safety of balloon pulmonary angioplasty for inoperable 
chronic thrombo-embolic pulmonary hypertension : long-term effects and procedure-related complications. Eur Heart J 2017 ; 38 : 3152-3159

20) Ota H, Higuchi S, Sun W, Ueda T, Takase K,
Tamura H : Four-dimensional flow magnetic resonance imaging for cardiovascular imaging: from basic concept to clinical application. Cardiovascular Imaging Asia 2018 ; 2 : 85-96

\title{
4D Flow MR Imaging for Pulmonary Hypertension
}

\author{
Hideki OTA \\ Department of Advanced MRI Collaboration Research, Tohoku University Graduate School of Medicine \\ 2-1 Seiryo-machi, Aoba-ku, Sendai 980-8575
}

Pulmonary hypertension is defined as a mean pulmonary artery pressure of $25 \mathrm{mmHg}$ or higher as detected by right heart catheterization. It is broadly classified into 5 categories based on the etiology. Various imaging modalities are used to evaluate patients with or suspected of pulmonary hypertension. Transthoracic echocardiography is the most frequently used modality for detecting pulmonary hypertension. Magnetic resonance imaging (MRI) is indicated during examination, since it allows for comprehensive image analysis of morphology, cardiac function, and hemodynamics in the great arteries. The recently developed 4D Flow MRI can visualize three-dimensional pulmonary vascular flow and measure advanced hemodynamic parameters. The degree of vertical flow in the pulmonary trunk may be a key aspect that reflects pulmonary hypertension. 4D Flow MRI can highlight the value of MRI for the clinical diagnosis and management of patients with pulmonary hypertension. 